\title{
ANALISIS HUBUNGAN KONDISI OSEANOGRAFI DENGAN FLUKTUASI HASIL TANGKAPAN IKAN PELAGIS DI SELAT SUNDA*)
}

\author{
Khairul Amri'1) \\ 1) Peneliti pada Pusat Riset Perikanan Tangkap, Ancol-Jakarta \\ Teregristrasi I tanggal: 27 Pebruari 2008; Diterima setelah perbaikan tanggal: 7 April 2008; \\ Disetujui terbit tanggal: 10 April 2008
}

\begin{abstract}
ABSTRAK
Tujuan riset ini adalah mengkaji hubungan antara kondisi oseanografi musiman (sebaran suhu permukaan laut, konsentrasi klorofil-a, pola arus, dan salinitas hasil pengukuran in situ dan data penginderaan jauh multi temporal tahun 2000, 2001, 2002, dan 2004) dengan hasil tangkapan ikan pelagis. Analisis dilakukan secara visual dan digital untuk mendapatkan gambaran dinamik kondisi oseanografi musiman perairan Selat Sunda. Hasil menunjukkan, nilai sebaran suhu permukaan laut Selat Sunda bervariasi sepanjang tahun, berkisar 27,0 sampai dengan $30,5^{\circ} \mathrm{C}$. Salinitas berkisar 31,0 sampai dengan $33,7 \%$ o dengan nilai terendah $(31,0 \%$ ) pada musim barat sementara salinitas tertinggi (32,7 sampai dengan 33,7\%) ditemukan pada musim peralihan 2. Sebaran klorofil-a berkisar 0,1 sampai dengan 2,0 $\mathrm{mg} \mathrm{m}^{-3}$. Musim barat merupakan musim dengan kandungan klorofil-a terendah $\left(0,1 \mathrm{mg} \mathrm{m}^{-3}\right)$ dan musim timur merupakan musim dengan tingkat kesuburan tertinggi (1,5 sampai dengan $2,0 \mathrm{mg} \mathrm{m}^{-3}$ ). Diduga peningkatan produktivitas primer yang sangat tinggi pada musim timur, selain akibat aliran massa air yang kaya nutrien dari Laut Jawa juga akibat upwelling pada mulut selat bagian selatan. Terdapat korelasi yang kuat antara peningkatan kosentrasi kesuburan perairan (klorofil-a tinggi 1,0 sampai dengan $1,5 \mathrm{mg} \mathrm{m}^{-3}$ ) akibat terjadi upwelling pada musim timur yang didukung oleh kondisi suhu permukaan laut hangat $\left(29,0\right.$ sampai dengan $\left.30,5^{\circ} \mathrm{C}\right)$ dan salinitas tinggi $(32,7$ sampai dengan $33,7 \%$ ) dengan diikuti peningkatan hasil tangkapan ikan.
\end{abstract}

KATAKUNCl: $\quad$ kondisi oseanografi, klorofil-a, hasil tangkapan ikan, Selat Sunda

ABSTRACT: Analysis of relationship between oceanographic condition with catch fluctuation of small pelagic fish in Sunda Strait. By: Khairul Amri

The current research aims to study the dynamic of the seasonal oceanography condition (sea surface temperature, chlorophyll-a concentration, sea surface height anomaly, and salinity by using in situ data and satellite multi temporal images until 2000, 2001, 2002, and 2004) in the Sunda Straits waters. The oceanographic data were analyzed by using visual and digital analyze to find the dynamic features. Results show that sea surface temperature was fluctuated with seasons. The values ranging from 27.0 to $30.5^{\circ} \mathrm{C}$ were higher than in situ measurement. The Surface salinity varied fluctuated from 31.0 to $33.7 \%$. Lower salinity (31.0\%) was found on the west monsoon, higher salinity (33.7\%) on the inter monsoon 2. The Concentration of chlorophyll-a ranged between 0.1 to $2.0 \mathrm{mg} \mathrm{m}^{-3}$ of which high abundance occurred with east monsoon. The high concentration of chlorophyll-a in east monsoon might be correlated to the nutrient transport impact from Java Sea and also contribution of upwelling process in southern mouth of Sunda Strait. The result shows that the catch of pelagic fish had strong linear correlation with the primery productivity (chlorophyll-a with high abundance 1.0 to $1.5 \mathrm{mg} \mathrm{m}^{-3}$ ) on upwelling process in east monsoon near south mouth of Sunda Straits with suported by warm water mass (sea surface temperature 29.0 to $30.5^{\circ} \mathrm{C}$ ) and high salinity (32.7 to $33.7 \%$ ).

KEYWORDS: $\quad$ oceanographic condition, clorophyll-a, fish yield, Sunda Strait

\section{PENDAHULUAN}

Selat Sunda merupakan salah satu perairan yang penting, baik ditinjau dari aspek oseanografi maupun dari aspek perikanan. Dinamika massa air dipengaruhi oleh aliran 2 massa air utama, yaitu massa air Laut Jawa dan Samudera Hindia. Pencampuran ke-2 massa air tersebut berdampak positif terhadap kualitas massa air selat, antara lain berpengaruh terhadap kandungan zat hara (nutrien), klorofil fitoplankton (kesuburan perairan) dan suspended solid/seston (Anonim, 2002).

Gambaran topografi Selat Sunda menunjukkan bahwa perairan ini memiliki gradasi kedalaman dari arah timur laut ke arah barat laut. Di bagian utara selat, kedalaman laut hanya sekitar $40 \mathrm{~m}$, kemudian berangsur-angsur dasar laut menurun ke arah barat daya dengan kedalaman laut sekitar 75 sampai dengan $100 \mathrm{~m}$. Selanjutnya, semakin ke arah barat

\footnotetext{
Makalah ini Merupakan Karya Tulis Terbaik Rumpun Riset Perikanan Tangkap pada Temu Karya Ilmiah 
daya, dasar laut tiba-tiba menurun sehingga kedalaman laut menjadi sekitar 700 sampai dengan 1.200 m (Anonim, 2002). Dengan demikian, maka pada bagian tengah perairan terdapat daerah tubir sebagai batas dasar perairan dangkal dengan perairan dalam yang pola memanjang utara selatan. Dari hasil penelitian secara in situ pada lokasi ini, ditemukan indikasi upwelling pada musim timur dan musim peralihan 2 (Muripto et al., 2000).

Ada fenomena upwelling tersebut juga dapat diamati dari data penginderaan jauh satelit (sensor visible) terhadap peningkatan sebaran klorofil-a seperti dikatakan Hendiarti et al., 2005; Amri et al., 2007. Dari analisis citra terlihat bahwa, pada ke-2 musim tersebut terjadi pengkayaan nutrien. Pengkayaan nutrien identik dengan peningkatan kesuburan perairan yang memiliki keterkaitan dengan kelimpahan sumber daya hayati. Pengamatan terhadap sebaran suhu dan pola arus menggunakan data penginderaan jauh satelit sensor thermal kaitan terhadap daerah potensi penangkapan ikan di Selat Sunda, dikatakan oleh Hasyim et al., 1995; Syamsudin et al., 2003.

Sumber daya ikan yang banyak dimanfaatkan di Selat Sunda terutama jenis-jenis ikan pelagis. Ikan pelagis adalah jenis ikan yang hidup atau menghuni perairan lapisan permukaan sampai dengan ke lapisan tengah (mid layer). Keberadaan sumber daya ikan pelagis sangat tergantung pada faktor-faktor lingkungan (kondisi oseanografi dan ketersediaan makanan) sehingga kelimpahan sangat berfluktuasi di suatu perairan. Perubahan suhu perairan yang sangat kecil $\left( \pm 0,02^{\circ} \mathrm{C}\right)$ dapat menyebabkan perubahan densitas populasi ikan di perairan tersebut (Laevastu \& Hayes, 1980). Pada perairan dengan kandungan zat hara tinggi, seperti di daerah upwelling, produksi plankton hampir selalu melimpah dan diikuti dengan produksi ikan yang cukup tinggi (Nybaken, 1992). Stok ikan pelagis juga sangat peka terhadap perubahan penyebaran spasial salinitas yang dibangkitkan oleh angin muson barat laut dan tenggara (Potier, 1988).

Pemanfaatan sumber daya perikanan pelagis di Selat Sunda dilakukan dengan menggunakan alat tangkap mini purse seine (pukat cincin mini). Armada pukat cincin mini yang dominan berpangkalan di Labuan, Pandeglang (Banten) dan sebagian lagi di Lempasing, Lampung. Daerah penangkapan (fishing ground) nelayan Labuan mencakup perairan bagian timur selat, membujur dari arah utara ke selatan mulai dari perairan sekitar Merak atau Cilegon sampai dengan ke sekitar Pulau Panaitan, Ujung Kulon (Muripto et al., 2000). Sementara mini purse seine nelayan Lempasing, beroperasi terbatas di perairan Teluk Lampung sekitar Pulau Legundi dan Sebuku (Hariati, 2005).

Tulisan ini membahas hubungan antara kondisi oseanografi terhadap hasil tangkapan ikan pelagis. Analisis difokuskan pada pengamatan musiman terhadap penampakan dinamik (dynamic features) kondisi oseanografi, kaitan dengan fluktuasi hasil tangkapan ikan pelagis kecil yang didaratkan di Labuan.

\section{BAHAN DAN METODE}

Lokasi pengamatan di seluruh perairan Selat Sunda $\left(05.00 .00^{\circ} \mathrm{LS}-07.00 .00^{\circ} \mathrm{LS}\right.$ dan $104.00 .00^{\circ} \mathrm{BT}$ $\left.106.30 .00^{\circ} \mathrm{BT}\right)$. Data hasil tangkapan ikan pelagis merupakan data hasil tangkapan armada pukat cincin mini yang didaratkan di tempat pendaratan ikan Labuan, Banten (Gambar 1).

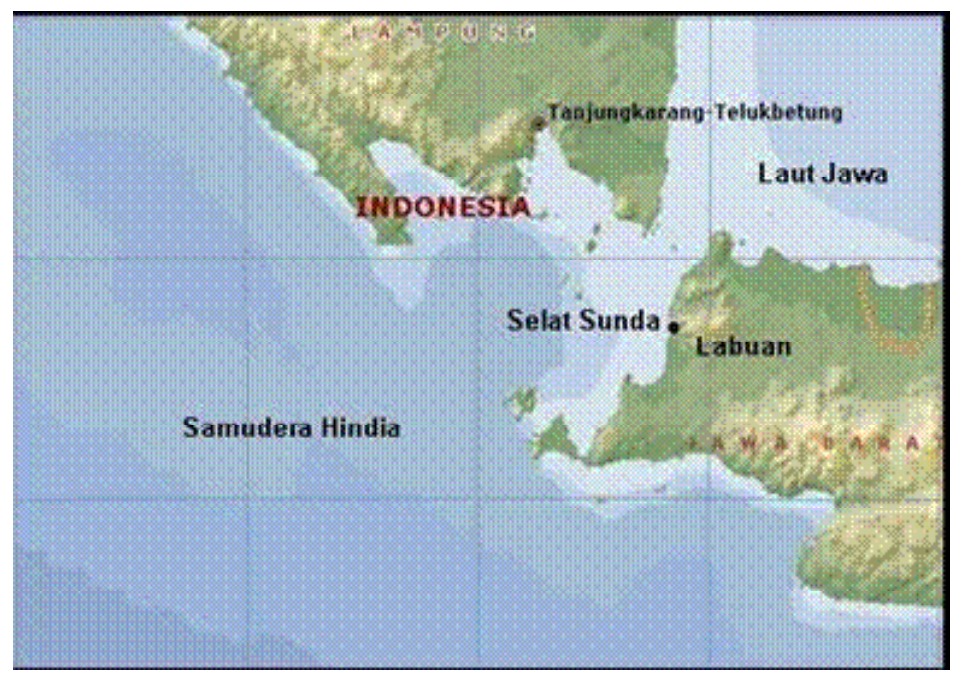

Gambar 1. Lokasi penelitian di perairan Selat Sunda.

Figure 1. Location of research in Sunda Strait waters. 
Beberapa aspek osenografi (sebaran suhu permukaan laut, klorofil-a, pola arus, dan anomali tinggi muka laut) yang digunakan, merupakan data hasil pengukuran satelit sensor visible dan thermal dikombinasikan dengan data hasil pengukuran in situ (Amri et al., 2007). Citra suhu permukaan laut diperoleh dari analisis data sensor advanced very high resolution radiometer satelit national oceanic and atmospheric administration 12. Citra klorofil-a merupakan data high resolution picture transmision sensor sea viewing wide field of view sensor satelit seastar. Untuk melihat pola kesuburan musiman dikomparasi dengan data referensi tahun 1997 sampai dengan 2004.

Data in situ, merupakan data cruise Pre Joint Indonesia-Germany Sumatera Expedition KAL Baruna Jaya IV Badan Pengkajian dan Penerapan Teknologi bulan Oktober 2000 ada 13 stasiun pengukuran; cruise K. R. Baruna Jaya VIII Lembaga Ilmu Pengetahuan Indonesia bulan Juli 2001 ada 23 stasiun pengukuran. Data in situ terdiri atas data hasil pengukuran conductivity temperature and depth Seacat Profiler V 4.0 tipe SBE 19 SEABIRD (suhu dan salinitas berdasarkan pada kedalaman); data acoustic dopler current propeler dan current meter (arah dan kuat arus). Untuk melihat pola dan nilai sebaran suhu permukaan laut, klorofil-a, arus, dan anomali tinggi muka laut dari citra satelit, dilakukan secara kuantitatif dan kualitatif mewakili 4 musim: musim timur (bulan Mei sampai dengan Juni sampai dengan Juli); musim barat (bulan Nopember sampai dengan Desember sampai dengan Januari); musim peralihan 1 (bulan Pebruari sampai dengan Maret sampai dengan April), dan musim peralihan 2 (bulan Agustus sampai dengan September sampai dengan Oktober). Analisis hubungan antara kondisi hidrologis

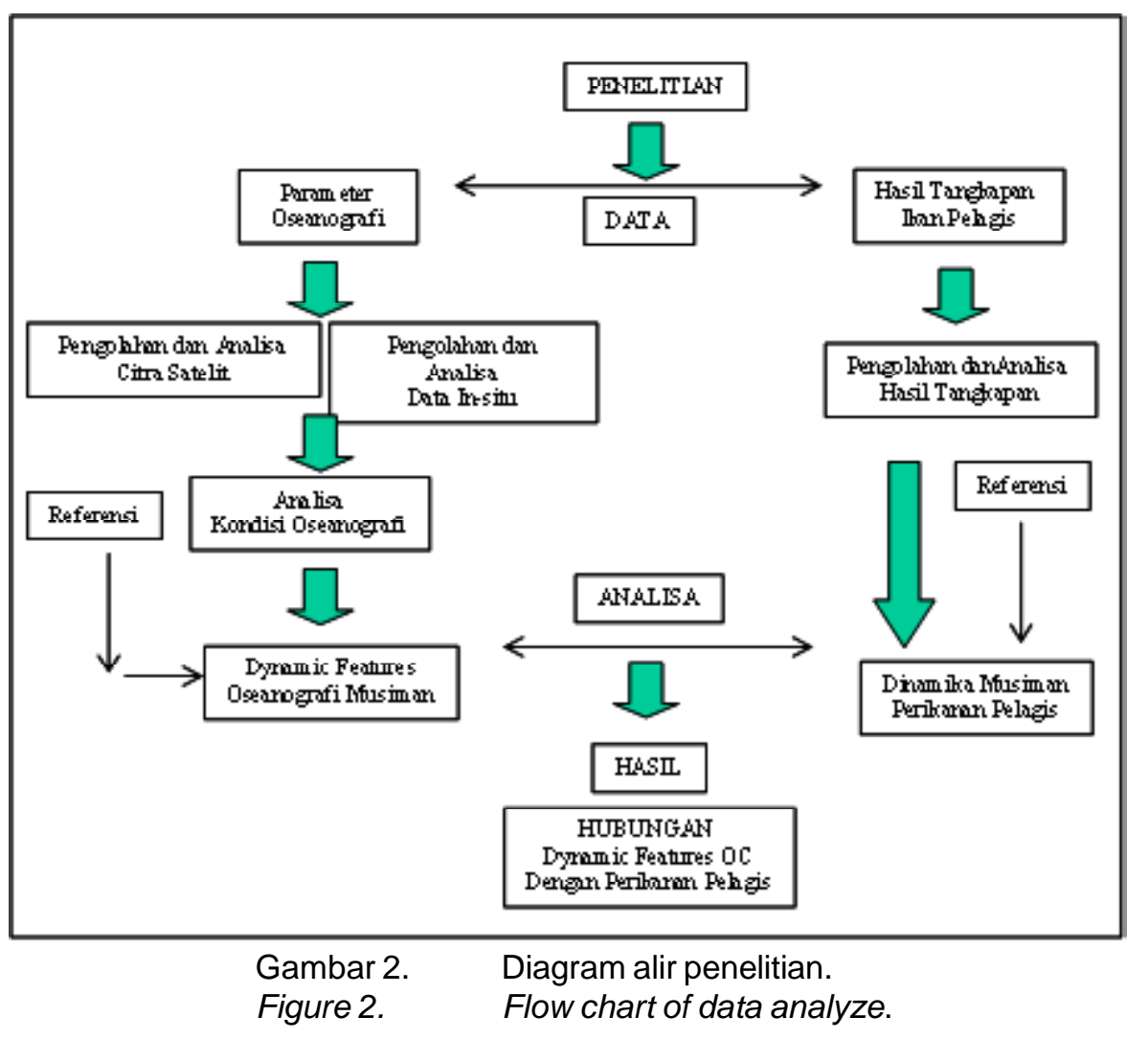

dengan hasil tangkapan dilakukan secara deskriptif. Diagram alir penelitian ditampilkan pada Gambar 2.

Dari pengamatan pola suhu permukaan laut sepanjang pengamatan terlihat ada pembagian 3 massa air di Selat Sunda berdasarkan pada HASIL DAN BAHASAN karakteristik nilai sebaran suhu permukaan laut, yakni massa air yang berasal dari Laut Jawa dan massa air 
yang berasal dari Samudera Hindia serta massa air yang merupakan pencampuran ke-2 massa air tersebut. Massa air dari Laut Jawa dicirikan dengan nilai suhu permukaan laut tinggi dan berada di bagian sebelah utara selat, sementara massa air dari Samudera Hindia memiliki nilai suhu permukaan laut yang lebih rendah dan berada di bagian selatan selat. Adapun posisi massa air campuran berada di tengah-
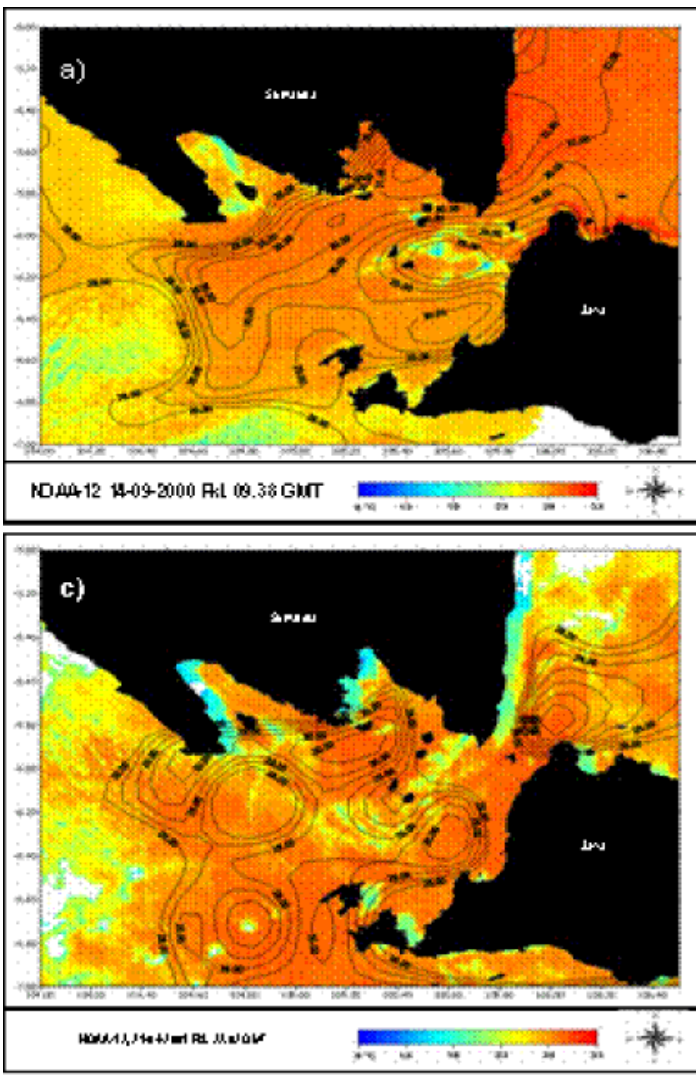

tengah selat, bersifat dinamis, dan bergeser ke utara atau ke selatan tergantung dorongan arus dominan (Hendiarti et al., 2005; Amri et al., 2007).

Dari pola sebaran suhu permukaan laut terlihat bahwa pada musim barat, ketika dorongan massa air Samudera Hindia dominan, massa air di Selat Sunda didominasi oleh massa air dengan suhu permukaan laut rendah dari Samudera Hindia, secara visual pada
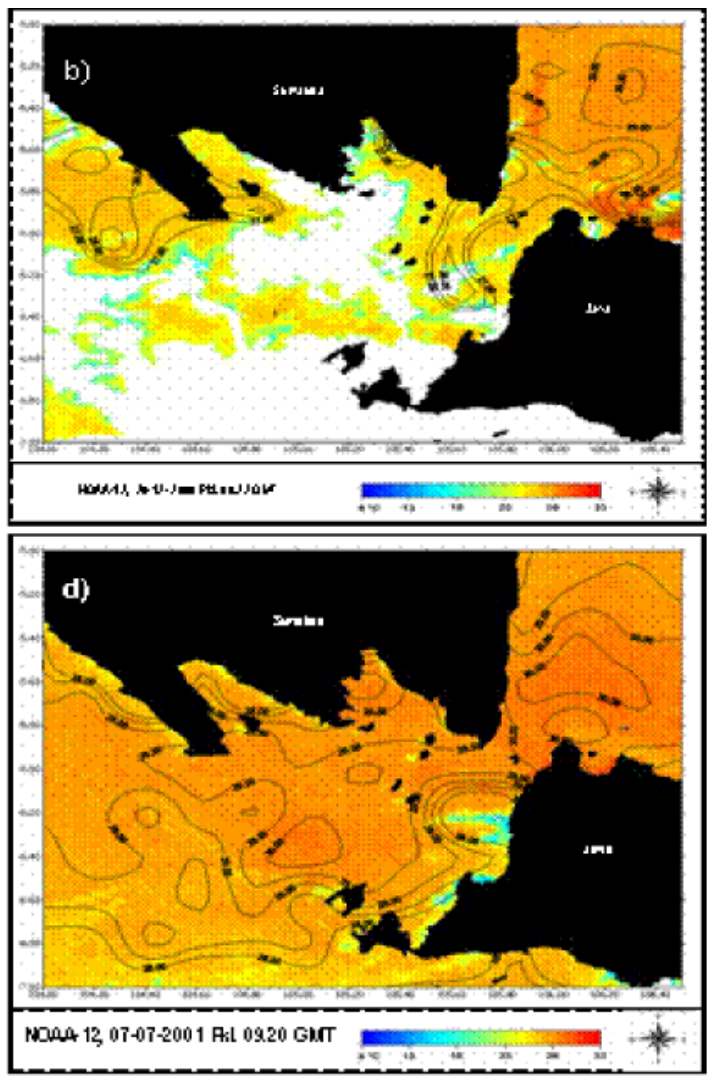

Gambar 3. Citra suhu permukaan laut perairan Selat Sunda (a. musim peralihan 2 bulan September 2000 ; b. musim barat bulan Desember 2000; c. musim peralihan 1 bulan April 2000; dan d. musim timur bulan Juli 2001).

Sumber: Amri et al. (2007)

Figure 3. Sea surface temperature images of Sunda Strait water (a. inter monsoon 2 month September 2000; b. west monsoon month December 2000; c. inter monsoon 1 month April 2000; and d. east monsoon month Juli 2001).

Sources: Amri et al. (2007)

citra terlihat dengan pola warna kuning muda. Sebaliknya, pada musim timur ketika massa air yang berasal dari Laut Jawa dengan suhu permukaan laut lebih hangat dominan, maka sebaran suhu permukaan laut di Selat Sunda didominasi oleh massa air dengan suhu permukaan laut hangat yang ditunjukkan dengan warna merah pada citra (Gambar 3).

Nilai sebaran suhu permukaan laut sepanjang tahun bervariasi, berkisar 27,0 sampai dengan $30,5^{\circ} \mathrm{C}$. Nilai sebaran suhu permukaan laut dari citra ini relatif tidak berbeda jauh dengan yang dikatakan Syamsudin et al. (2003) yang mengatakan bahwa suhu permukaan laut Selat Sunda sama dengan perairan lain di Indonesia berkisar 28,0 sampai dengan $29,5^{\circ} \mathrm{C}$. Musim barat kondisi suhu permukaan laut didominasi massa air bersuhu rendah dengan kisaran 27,0 sampai dengan $29,0^{\circ} \mathrm{C}$. Musim timur merupakan musim dengan kondisi suhu permukaan laut relatif tinggi didominasi oleh massa air dengan suhu permukaan laut 29,0 sampai dengan $30,5^{\circ} \mathrm{C}$. Pada musim peralihan 1 dan 2 nilai sebaran suhu permukaan laut berkisar 27,0 sampai dengan $30,5^{\circ} \mathrm{C}$. Nilai sebaran suhu permukaan laut pengukuran satelit 
Tabel 1. Perbandingan nilai suhu permukaan laut Selat Sunda hasil pengukuran sensor satelit dengan pengukuran in situ

Table 1. Comparasing the sea surface temperature value from satelitte images and in situ measurement

\begin{tabular}{|c|c|c|c|}
\hline \multirow{2}{*}{ Musim/Season } & \multirow{2}{*}{ Bulan/Month } & \multicolumn{2}{|c|}{ Suhu/Temperature $\left({ }^{\circ} \mathrm{C}\right)$} \\
\hline & & Satelit/Satelitte & In situ \\
\hline \multirow[t]{3}{*}{ Musim peralihan 2} & Agustus & $29,0-29,5$ & $28,0-29,7$ \\
\hline & September & $28,0-30,5$ & \\
\hline & Oktober & $29,5-30,5$ & \\
\hline \multirow[t]{3}{*}{ Musim barat } & Nopember & $28,0-29,0$ & \\
\hline & Desember & $27,0-28,0$ & \\
\hline & Januari & $27,0-29,0$ & \\
\hline \multirow[t]{3}{*}{ Musim peralihan 1} & Pebruari & $27,0-29,0$ & \\
\hline & Maret & $29,0-30,5$ & \\
\hline & April & $29,0-30,0$ & \\
\hline \multirow[t]{3}{*}{ Musim timur } & Mei & $28,0-30,0$ & $29,1-29,6$ \\
\hline & Juni & $29,0-30,5$ & \\
\hline & Juli & $29,0-30,5$ & \\
\hline
\end{tabular}

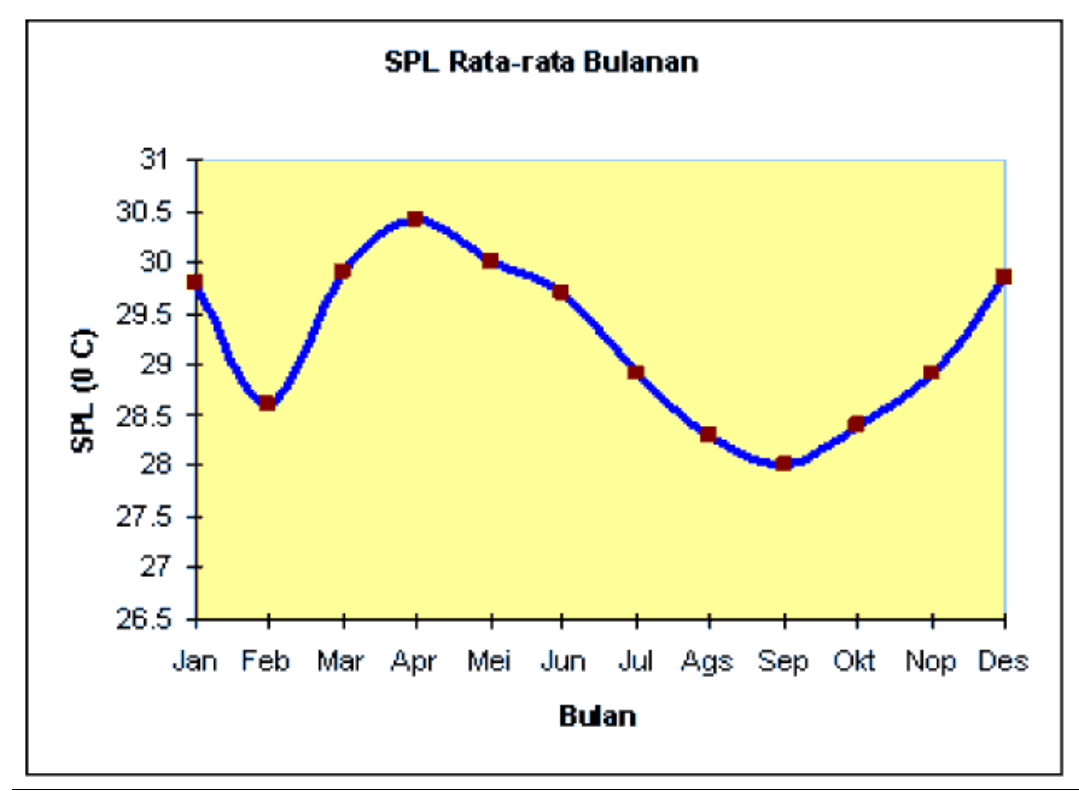

Gambar 4. Fluktuasi suhu permukaan laut rata-rata bulanan tahun 1997sampai dengan 2004. Sumber: diolah dari Hendiarti et al. (2005)

Figure 4. Sea surface temperature montly everage 1997 to 2004.

Sources: Analyzed from Hendiarti et al. (2005)

sedikit lebih tinggi dibanding pengukuran in situ (Tabel 1).

Sementara nilai sebaran suhu permukaan laut ratarata bulanan yang dianalisis sepanjang tahun 1997 sampai dengan 2004 menunjukkan sedikit perbedaan yaitu berkisar antara 28,0 sampai dengan $30,4^{\circ} \mathrm{C}$ seperti terlihat pada grafik (Gambar 4).

Indikasi ada dominansi massa air hangat yang berasal dari Laut Jawa seperti terdeteksi citra suhu permukaan laut pada musim peralihan 2, diperkuat hasil pengamatan anomali tinggi permukaan laut pada waktu yang sama bernilai positif $(30 \mathrm{~cm})$, sekaligus menunjukkan arus dominan dari Laut Jawa. Pada musim barat, dominansi massa air dingin (suhu permukaan laut rendah) dari Samudera Hindia yang masuk ke Selat Sunda didukung dengan nilai anomali tinggi permukaan laut negatif $(-5 \mathrm{~cm}$ ) (Amri et al., 2007).

\section{Pola Sebaran Salinitas}

Dari data hasil pengukuran salinitas in situ dan data referensi menunjukkan nilai salinitas permukaan Selat Sunda berkisar antara 31,0 sampai dengan $33,7 \%$ dan berfluktuasi menurut musim. Salinitas terendah $(31,0 \%$ ) ditemukan pada musim barat dan 

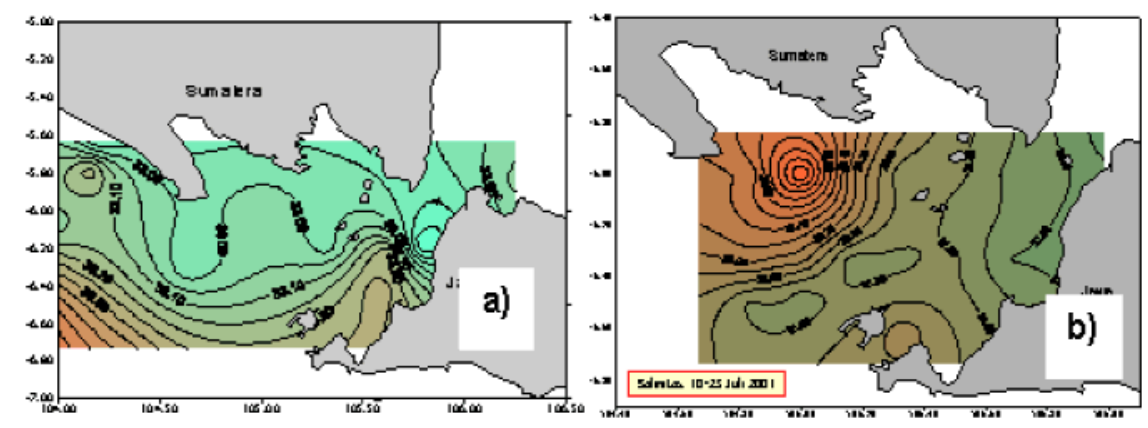

Gambar 5. Sebaran mendatar salinitas permukaan (a. bulan Oktober 2000 musim peralihan 2 dan b. bulan Juli 2001 musim timur).

Sumber: Amri et al. (2007)

Figure 5. Distribution of surface salinity of Sunda Strait (a. October 2000 inter monsoon 2 and b. July 2001 east monsoon).

Sources: Amri et al. (2007)

musim peralihan 1 , salinitas tertinggi ditemukan pada musim peralihan 2 dan musim timur dengan nilai masing-masing 32,7 sampai dengan $33,7 \%$ dan 31,4 sampai dengan $32,6 \%$. Pola sebaran salinitas permukaan pada musim peralihan 2 dan musim timur ditampilkan pada (Gambar 5).

Massa air dengan salinitas lebih rendah $(32,7$ sampai dengan $33,0 \%$ ) berada di bagian utara dan timur selat yang berhubungan dengan Laut Jawa dan massa air dengan salinitas lebih tinggi ( 33,1 sampai dengan $33,7 \%$ ) berada di bagian selatan dan barat selat. Massa air dengan salinitas tinggi (warna merah) berasal dari Samudera Hindia dan pada musim peralihan 2 (Gambar 3a) memasuki bagian tengah selat ke arah Teluk Labuan melalui Selat Panaitan dan membentuk front dengan massa air bersalinitas lebih rendah (warna biru) dari Laut Jawa. Pada musim timur (Gambar 3b) massa air dengan salinitas tinggi selain berada di sekitar Pulau Panaitan juga menyebar luas ke arah Teluk Semangka. Pola sebaran salinitas ini terlihat memiliki kesamaan dengan pola sebaran suhu permukaan laut. Pola sebaran menegak suhu dan salinitas menunjukkan bahwa lapisan termoklin di Selat Sunda pada umumnya ditemukan pada kedalaman sekitar 75 sampai dengan $100 \mathrm{~m}$.

\section{Pola Arus}

Arus pada musim timur menunjukkan arus dominan di lapisan permukaan sampai dengan kedalaman sekitar $50 \mathrm{~m}$ dari timur laut (mulut selat bagian utara) menuju ke arah barat daya dengan kecepatan yang relatif kuat. Sedangkan pada kedalaman 50 sampai dengan $100 \mathrm{~m}$, terutama di bagian tengah selat, terlihat indikasi terjadi

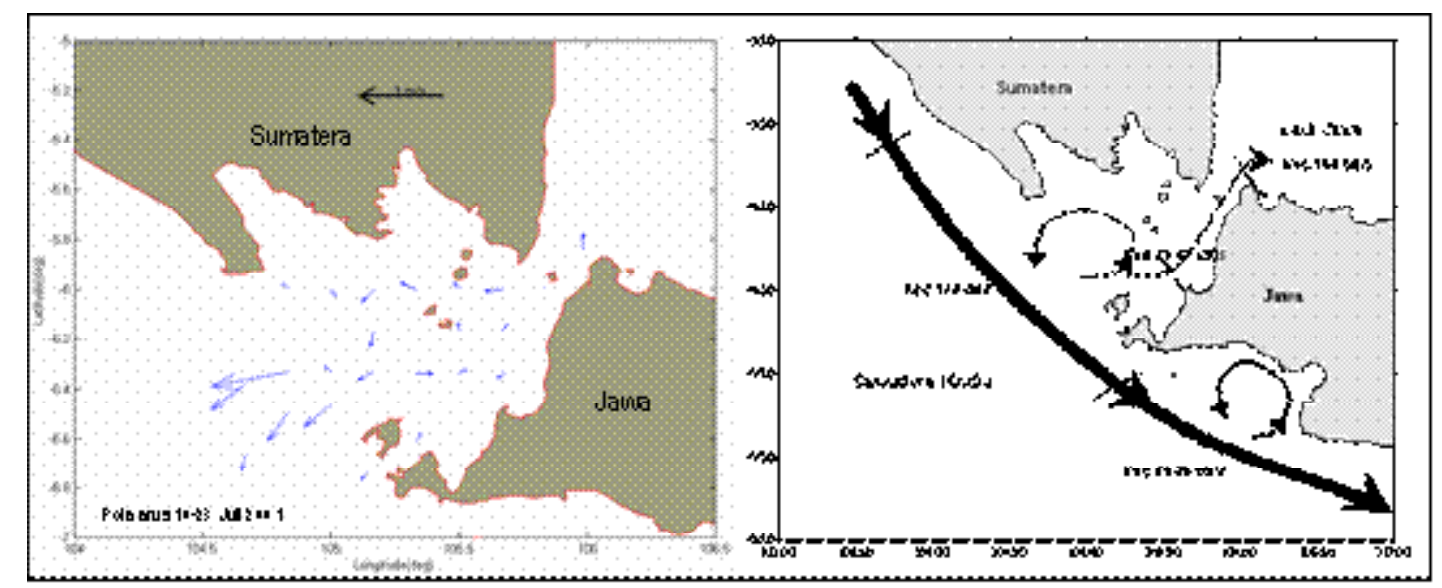

Gambar 6. Pola arus permukaan perairan Selat Sunda pada musim timur bulan Juni sampai dengan Juli (kiri) dan musim peralihan 2 bulan Oktober (kanan).

Sumber: Amri et al. (2007)

Figure 6. Surface current of Sunda Strait on east monsoon month Juni to Juli (left) and inter monsoon 2 month October (right).

Sources: Amri et al. (2007) 
penyusupan air dari lapisan dalam Samudera Hindia ke arah timur laut. Tetapi karena laut semakin mendangkal dan pada lapisan permukaan terdapat arus dengan arah yang berlawanan, maka massa air tersebut berbelok ke kiri dan kemudian berbalik arah kembali ke Samudera Hindia (Gambar 6).

Pola arus pada musim peralihan 2 menunjukkan di bagian luar selat sebelah selatan, arus dominan bergerak dari arah barat menuju ke timur menyusuri sepanjang pantai barat Sumatera dan selatan Jawa dengan kecepatan tinggi. Sebagian besar massa air yang terdorong ke dalam selat tertahan oleh gugusan pulau-pulau kecil (Pulau Panaitan, Rakata, dan Sertung) yang membelokkan arah massa air kembali ke arah mulut selat bagian selatan. Sebagian kecil massa air yang bergerak menyusuri pesisir Banten (Labuan) terdorong menuju ke arah mulut selat sebelah utara. Kondisi ini perlu diperdebatkan mengingat hasil penelitian Wyrtki (1962) yang mengatakan bahwa aliran massa air di Selat Sunda dan Samudera Hindia selalu berasal dari Laut Jawa, terlihat dengan ada perluasan massa air yang lebih panas ke arah selatan.

\section{Sebaran Klorofil-a}

Musim peralihan 2 dan musim timur merupakan musim dengan tingkat kesuburan tinggi ditunjukkan dengan sebaran klorofil-a masing-masing berkisar 1,0 sampai dengan $1,5 \mathrm{mg} \mathrm{m}^{-3}$ dan 1,5 sampai dengan 2,0 $\mathrm{mg} \mathrm{m}^{-3}$. Musim barat merupakan musim dengan kandungan klorofil-a terendah dengan kisaran 0,1 sampai dengan $1,0 \mathrm{mg} \mathrm{m}^{-3}$ dan musim peralihan 1 memiliki tingkat sebaran klorofil-a sedang berkisar 0,8 sampai dengan $1,5 \mathrm{mg} \mathrm{m}^{-3}$ (Gambar 7). Fluktuasi ratarata konsentrasi klorofil-a bulanan ditampilkan pada grafik (Gambar 8).

Dari pola sebaran terlihat bahwa tinggi rendah kandungan klorofil-a sangat dipengaruhi oleh aliran massa air yang berasal dari Laut Jawa yang mengandung klorofil-a dengan konsentrasi tinggi (bulan April, Juli, dan Desember). Kondisi fisik perairan seperti suhu permukaan laut dan arus sebagaimana diuraikan di atas, ternyata berpengaruh terhadap kandungan klorofil-a di perairan. Pada lapisan

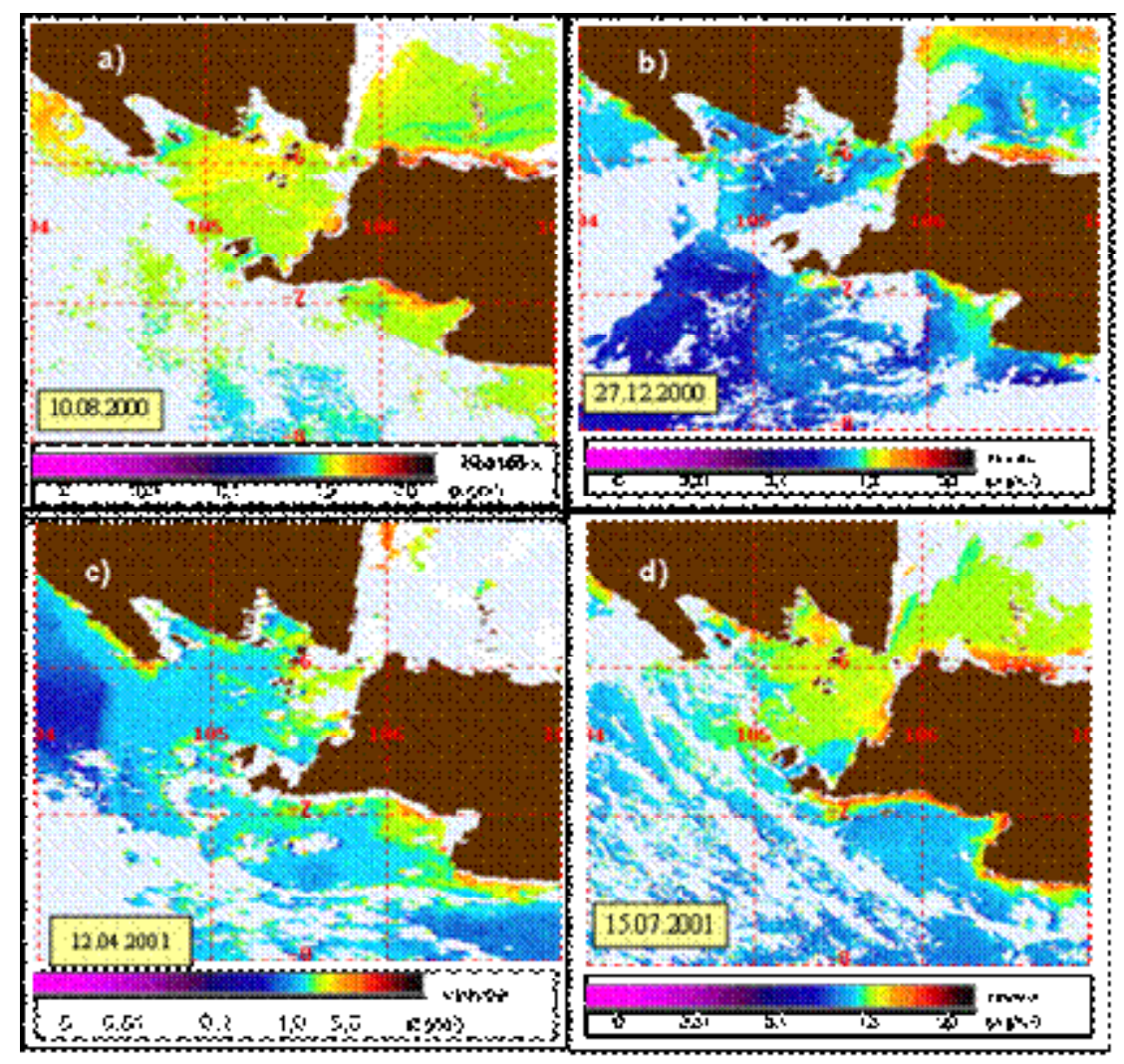

Gambar 7. Citra sebaran klorofil-a musiman Selat Sunda (a. bulan Agustus; b. bulan Desember; c. bulan April; dan d. bulan Juli).

Sumber: Amri et al. (2007)

Figure 7. Seasonal variation of klorofil-a images of Sunda Strait (a. month August; b. month December; c. month April; and d. month July.

Sources: Amri et al. (2007) 


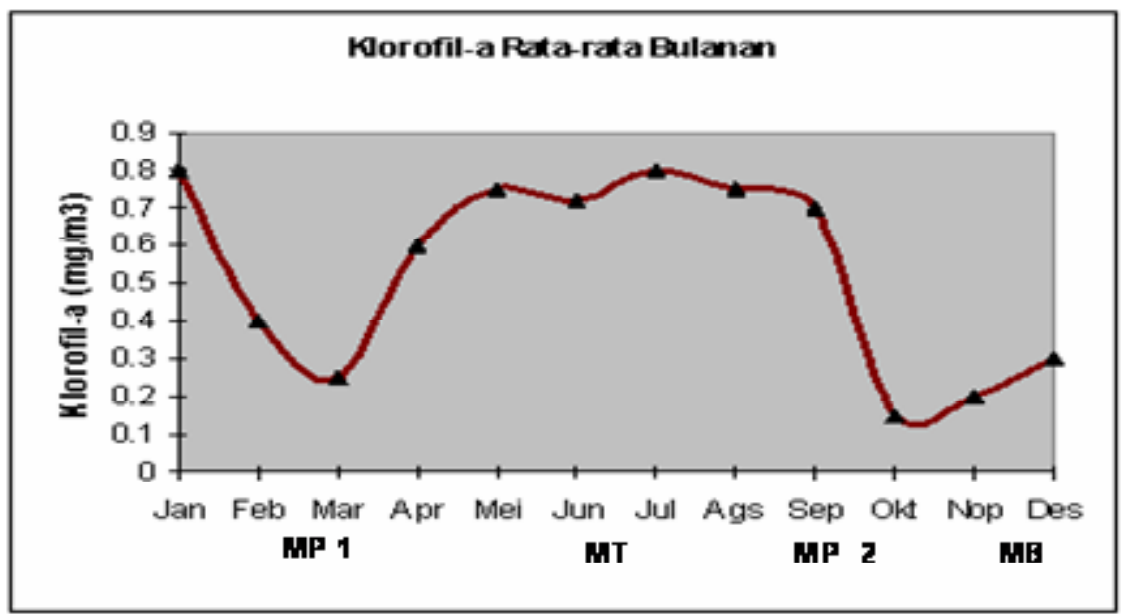

Gambar 8. Fluktuasi klorofil-a bulanan tahun 1997 sampai dengan 2004. Sumber: diolah dari Hendiarti et al. (2005)

Figure 8. Montly fluctuation of chlorphyll-a during 1997 to 2004.

Sources: Analyzed from Hendiarti et al. (2005)

permukaan, dengan arus yang relatif kuat dari arah timur (Laut Jawa) menuju Samudera Hindia terutama pada musim timur dan musim peralihan, membawa unsur hara dan dimanfaatkan penuh oleh fitoplankton untuk berkembang di sebagian besar lokasi di Selat Sunda.

Dari data hasil pengukuran in situ, klorofil-a dengan kosentrasi yang tinggi pada umumnya ditemukan di perairan-perairan yang terlindung di sepanjang pantai
Banten bagian barat dan di sekitar pulau-pulau di Selat Sunda seperti Pulau Sangiang dan Rakata. Pada daerah-daerah yang terlindung tersebut kadar klorofil hasil pengukuran relatif tinggi berkisar antara 0,25 sampai dengan $0,75 \mathrm{mg} \mathrm{m}^{-3}$ (Anonim, 2002). Nilai sebaran klorofil hasil pengukuran in situ ini lebih rendah dibandingkan dengan nilai sebaran pada citra satelit. Tinggi nilai sebaran klorofil-a hasil pengukuran in situ untuk daerah-daerah yang terlindung dan di sekitar pulau-pulau diduga karena tertahan massa air yang mengandung unsur hara sehingga memberi

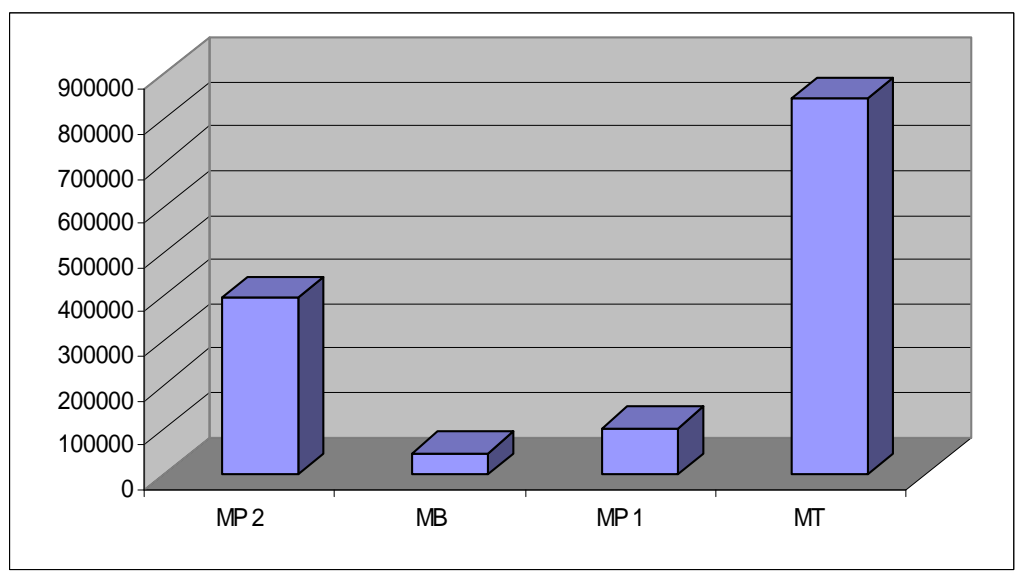

Gambar 9. Total hasil tangkapan ikan pelagis per musim (bulan Agustus 2000 sampai dengan Juli 2001) di Selat Sunda.

Figure 9. Total catch of pelagic fish by season (August 2000 until July 2001) in Sunda Strait.

kesempatan pada plankton untuk tumbuh. Sebaliknya, pada perairan yang lebih terbuka kecepatan pertumbuhan plankton lebih lambat dibandingkan kecepatan arus, sehingga plankton kemungkinan besar terbawa arus ke bagian barat laut atau bagian selatan selat sebelum sempat tumbuh dan berkembang.

Pada bulan Agustus (akhir musim timur) juga terlihat kosentrasi klorofil-a yang tinggi di perairan 

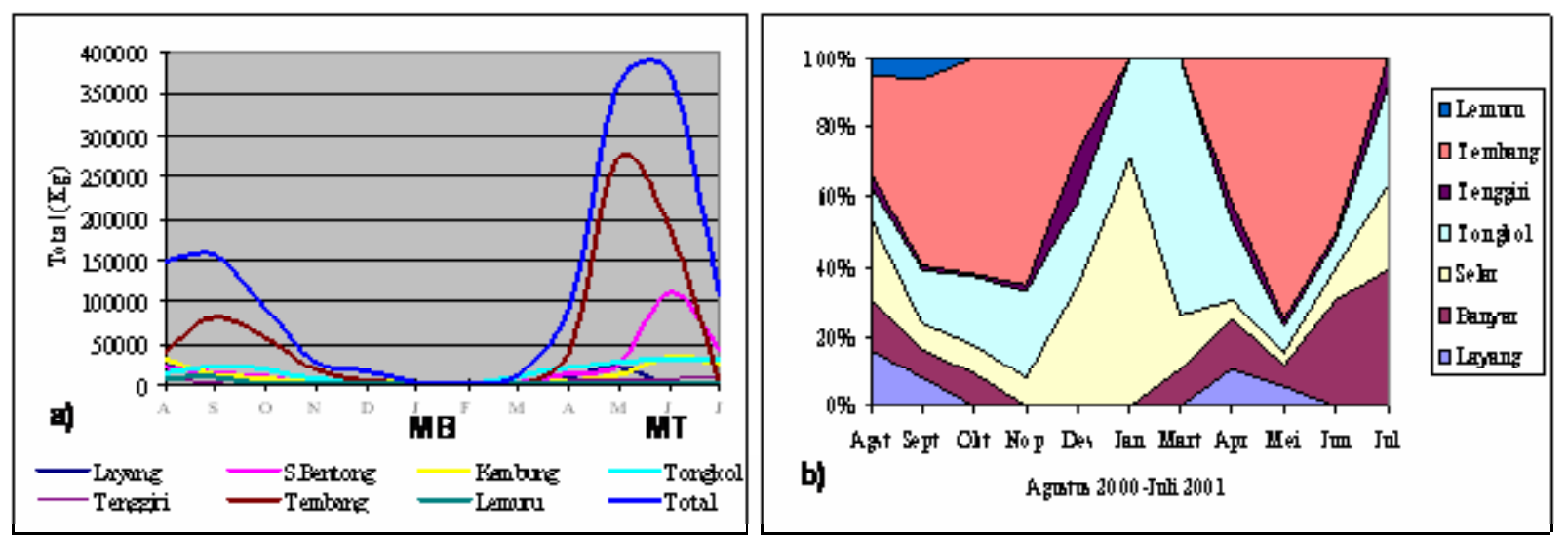

Gambar 10. Fluktuasi hasil tangkapan (a) dan komposisi hasil tangkapan bulanan (b) ikan pelagis di Selat Sunda bulan Agustus 2000 sampai dengan Juli 2001.

Figure 10. Catch fluctuation of small pelagic fish (a) and monthly composition of small pelagic fish catch (b) in Sunda Strait during August 2000 to July 2001.

lepas pantai di bagian selatan selat. Meskipun lokasi ini tidak mendapat pengaruh langsung suplai nutrien dari daratan (run off) dan aliran massa air Laut Jawa, tetapi memiliki nilai klorofil-a yang tinggi. Peningkatan sebaran klorofil-a di lepas pantai bagian selatan Selat Sunda ini diduga terkait dengan peningkatan unsur hara yang dihasilkan melalui proses fisik massa air berupa upwelling. Hal ini, sejalan dengan temuan Hendiarti et al. (2005) yang mengatakan ada indikasi peningkatan klorofil-a di selatan Jawa (termasuk selatan Selat Sunda dan Pelabuhan Ratu) pada musim tenggara atau musim timur yakni pada bulan Juni sampai dengan Oktober.

\section{Hasil Tangkapan Ikan Pelagis}

Total hasil tangkapan ikan pelagis per musim menunjukkan bahwa hasil tangkapan periode musim timur tertinggi diikuti pada musim peralihan 2. Hasil tangkapan terendah pada musim barat dan musim peralihan 1 (Gambar 9). Gambar 10 menunjukkan fluktuasi (a) dan komposisi hasil tangkapan dalam persentase (b) per bulan.

Terlihat ada kesamaan pola muncul ikan pelagis di Selat Sunda yang mulai tertangkap pada bulan Maret (musim peralihan 1) dan hasil tangkapan menunjukkan pola menaik memasuki musim timur sebagai puncak penangkapan. Sebaliknya, pola penurunan hasil tangkapan terlihat ketika mulai berakhir musim peralihan 2 yang selanjutnya mencapai titik terendah pada musim barat (Gambar 10a).

Tinggi hasil tangkapan pada musim timur dan musim peralihan 2 , diduga terkait dengan kondisi oseanografi yang optimum dengan suhu permukaan laut hangat 29,0 sampai dengan $30,5^{\circ} \mathrm{C}$, kandungan klorofil-a tinggi ( 1,5 sampai dengan $\left.2,0 \mathrm{mg} \mathrm{m}^{-3}\right)$ yang menandakan tingkat kesuburan perairan tinggi dan sebaran salinitas optimum (tertinggi $33,7 \%$ ). Sebaliknya, hasil tangkapan yang rendah pada musim barat dan musim peralihan 1 , diduga terkait dengan suhu permukaan laut yang rendah $(27,0$ sampai dengan $29,0^{\circ} \mathrm{C}$ ), kesuburan rendah (sebaran klorofil-a 0,1 sampai dengan $1,0 \mathrm{mg} \mathrm{m}^{-3}$ ) serta salinitas yang juga rendah. Pada bulan Januari terjadi penurunan salinitas perairan di Selat Sunda dari 33 sampai dengan $34 \%$ menjadi 32 sampai dengan $33 \%$ 。 Wyrtky et al. (1971) dalam Birowo \& Uktolseja (1981). Terlihat bahwa kondisi yang demikian direspon oleh ikan-ikan pelagis dengan melakukan ruaya ke lokasi atau perairan lain yang lebih sesuai, sehingga hasil tangkapan di perairan ini sangat rendah.

Dari komposisi hasil tangkapan (Gambar 10b) pada musim timur, jenis ikan yang dominan tertangkap adalah ikan tembang (Sardinella fimbriata), ikan banyar (Rastrelliger kanagurta), ikan layang (Decapterus sp.), dan ikan selar (Selar crumenopthalmus). Pada musim barat, ikan yang dominan tertangkap adalah ikan selar (Selar crumenopthalmus), ikan tongkol (Euthynnus sp.), dan ikan tenggiri (Scomberomorus sp.). Pada musim peralihan 1, ikan pelagis yang dominan tertangkap adalah ikan tongkol (Euthynnus sp.) dan ikan selar (Selar crumenopthalmus); dan pada musim peralihan 2 ikan yang dominan tertangkap adalah ikan tembang (Sardinella fimbriata), ikan tongkol (Euthynnus sp.), ikan selar (Selar crumenopthalmus), ikan layang (Decapterus sp.), dan ikan lemuru (Sardinella sp.). 
Tabel 2. Karakteristik oseanografi dan hasil tangkapan ikan pelagis di Selat Sunda Table 2. The oceanographic caracteristic and pelagic fish catch in Sunda Strait

\begin{tabular}{|c|c|c|c|c|c|c|}
\hline \multirow{2}{*}{$\begin{array}{l}\text { Musim/ } \\
\text { Season }\end{array}$} & \multicolumn{3}{|c|}{$\begin{array}{c}\text { Kondisi oseanografi/ } \\
\text { Condition oceanographic }\end{array}$} & \multirow{2}{*}{$\begin{array}{c}\text { Kesuburan perairan/ } \\
\text { Chlorophyll-a } \\
\text { concentration }\end{array}$} & \multirow{2}{*}{$\begin{array}{l}\text { Hasil tangkapan/ } \\
\text { Fish catch }\end{array}$} & \multirow{2}{*}{$\begin{array}{l}\text { Jenis ikan/ } \\
\text { Species }\end{array}$} \\
\hline & $\begin{array}{c}\text { Suhu/ } \\
\text { Temperature } \\
\left({ }^{\circ} \mathrm{C}\right)\end{array}$ & $\begin{array}{c}\text { Salinitas/Salinity } \\
\text { (per mil) }\end{array}$ & $\begin{array}{l}\text { Arus/ } \\
\text { Curent }\end{array}$ & & & \\
\hline $\begin{array}{l}\text { Musim peralihan } 2 \\
\text { (bulan September- } \\
\text { Oktober) }\end{array}$ & $28,0-30,5$ & $\begin{array}{l}\text { Tinggi } \\
32,7-33,7\end{array}$ & $\begin{array}{l}\text { Kuat } \\
\text { dari Laut Jawa } 60 \mathrm{~cm} \\
\text { per detik }\end{array}$ & $\begin{array}{l}\text { Tinggi } \\
1,0-1,5 \mathrm{mg} \mathrm{m}^{-3}\end{array}$ & Sedang (28\%) & $\begin{array}{l}\text { lkan tembang, ikan } \\
\text { tongkol, ikan selar, ikan } \\
\text { banyar, ikan layang, dan } \\
\text { ikan lemuru }\end{array}$ \\
\hline $\begin{array}{l}\text { Musim barat (bulan } \\
\text { Nopember-Desember- } \\
\text { Januari-Pebruari) }\end{array}$ & $27,0-28,0$ & $\begin{array}{l}\text { Rendah } \\
31,0^{*}\end{array}$ & $\begin{array}{l}\text { Kuat } \\
\text { dari Samudera Hindia } \\
>40 \mathrm{~cm} \text { per s }\end{array}$ & $\begin{array}{l}\text { Rendah } \\
0,1-1,0 \mathrm{mg} \mathrm{m}^{-3}\end{array}$ & Rendah (3\%) & $\begin{array}{l}\text { Ikan selar, ikan tongkol, } \\
\text { dan ikan tenggiri }\end{array}$ \\
\hline $\begin{array}{l}\text { Mperalihan } 1 \\
\text { (bulan Maret-April) }\end{array}$ & $27,0-29,0$ & $\begin{array}{l}\text { Rendah } \\
31,0^{\star}\end{array}$ & $\begin{array}{l}\text { Lemah atau tidak ada } \\
\text { dominansi arus }\end{array}$ & $\begin{array}{l}\text { Sedang } \\
0,8-1,0 \mathrm{mg} \mathrm{m}^{-3}\end{array}$ & Rendah (7\%) & $\begin{array}{l}\text { Ikan tongkol dan ikan } \\
\text { selar }\end{array}$ \\
\hline $\begin{array}{l}\text { Musim timur } \\
\text { (bulan Mei-Juni-Juli- } \\
\text { Agustus) }\end{array}$ & $29,0-30,5$ & $\begin{array}{l}\text { Sedang } \\
31,4-32,6\end{array}$ & $\begin{array}{l}\text { Sedang } \\
\text { dari Laut Jawa }\end{array}$ & $\begin{array}{l}\text { Tinggi } \\
1,5-2,0 \mathrm{mg} \mathrm{m}^{-3}\end{array}$ & Tinggi (62\%) & $\begin{array}{l}\text { lkan tembang, ikan } \\
\text { banyar, ikan layang, ikan } \\
\text { tongkol, dan ikan selar }\end{array}$ \\
\hline
\end{tabular}

\section{Hubungan Kondisi Oseanografi dengan Hasil Tangkapan}

Tabel 2 memperlihatkan kaitan antara fenomena oseanografi berdasarkan pada pengamatan per musim dengan hasil dan jenis ikan pelagis yang tertangkap.

Tertangkap ikan layang (Decapterus sp.) dan ikan banyar (Rastrelliger kanagurta) (musim timur dan peralihan 2) serta ikan lemuru (Sardinella sp.) (musim peralihan-2) menandakan bahwa pada saat tersebut kondisi oseanografi optimum bagi kehidupannya terutama kondisi salinitas tinggi, mengingat ketiga jenis ikan tersebut bersifat oseanik. Penurunan salinitas di bawah 33\%。 pada musim barat, musim peralihan 1, dan musim timur membuat ikan lemuru (Sardinella sp.) berpindah dari Selat Sunda yang ditandakan dengan tidak tertangkap jenis ikan ini selain pada musim peralihan 2 yang memiliki salinitas $>33 \%$. Kondisi yang sama terjadi pada ikan banyar (Rastrelliger kanagurta) dan ikan layang (Decapterus sp.) yang tidak tertangkap sama sekali pada musim barat, diduga terkait salinitas yang rendah berkenaan dengan musim hujan. Ikan selar (Selar crumenopthalmus) yang dominan tertangkap periode musim barat dan musim peralihan 1 merupakan fenomena yang umum terjadi di Selat Sunda karena merupakan jenis ikan penghuni pantai dan teluk yang terlindung (coasta). Pada musim barat, penangkapan banyak dilakukan di perairan dekat pantai dan teluk yang terlindung dari ombak dan arus kencang. Satu hal menarik, ternyata ikan tongkol (Euthynnus sp.) merupakan jenis ikan yang selalu tertangkap sepanjang musim, diduga sebagai sumber daya neritik mampu menyesuaikan diri dengan dinamika oseanografi yang terjadi.

\section{KESIMPULAN}

1. Nilai suhu permukaan laut Selat Sunda bervariasi sepanjang tahun, tergantung musim. Nilai suhu permukaan laut terendah $\left(27,0^{\circ} \mathrm{C}\right)$ pada musim barat dan nilai tertinggi $\left(30,5^{\circ} \mathrm{C}\right)$ pada musim timur dan musim peralihan 2. Salinitas berkisar 31,0 sampai dengan $33,7 \%$, dengan nilai terendah $(31,0 \%$ ) pada musim barat sementara tertinggi (32,7 sampai dengan $33,7 \%$ ) pada musim peralihan 2.

2. Musim barat merupakan musim dengan kandungan klorofil-a terendah $\left(0,1 \mathrm{mg} \mathrm{m}^{-3}\right)$ dan musim peralihan 2 serta musim timur, merupakan musim dengan tingkat kesuburan tertinggi $(1,5$ sampai dengan $2,0 \mathrm{mg} \mathrm{m}^{-3}$ ). Diduga, peningkatan produktivitas primer pada musim timur selain akibat aliran massa air yang kaya nutrien dari Laut Jawa, juga akibat proses upwelling di mulut selat bagian selatan.

3. Ikan tembang (Sardinella fimbriata), ikan tongkol (Euthynnus sp.), ikan selar (Selar crumenopthalmus), ikan layang (Decapterus sp.), dan ikan lemuru (Sardinella sp.), di Selat Sunda banyak tertangkap pada musim peralihan 2 (bulan September sampai dengan Oktober) dengan kondisi sebaran suhu permukaan laut 28,0 sampai dengan $30,5^{\circ} \mathrm{C}$, sedangkan pada musim timur (bulan Mei sampai dengan Juni sampai dengan Juli sampai dengan Agustus) dengan sebaran suhu 
29,0 sampai dengan $30,5^{\circ} \mathrm{C}$, klorofil-a 1,5 sampai dengan $2,0 \mathrm{mg} \mathrm{m}^{-3}$, salinitas 31,4 sampai dengan 32,6 dan arus berasal dari Laut Jawa, banyak tertangkap ikan tembang (Sardinella fimbriata), ikan layang (Decapterus sp.), ikan banyar (Rastrelliger kanagurta), ikan tongkol (Euthynnus sp.), dan ikan selar (Selar crumenopthalmus). Musim barat (bulan Nopember sampai dengan Desember sampai dengan Januari) merupakan musim paceklik, hanya tertangkap jenis ikan tongkol (Euthynnus sp.) dan ikan selar (Selar crumenopthalmus). Dalam penelitian ini terlihat bahwa musim peralihan 1 (bulan Pebruari sampai dengan Maret sampai dengan April) merupakan musim awal keberadaan ikan di Selat Sunda dan mencapai puncak pada musim timur.

\section{PERSANTUNAN}

Review-review bagian dari hasil riset thesis penulis tahun 2002.

\section{DAFTAR PUSTAKA}

Amri K., D. Manurung, \& V. P. Siregar. 2007. Dinamika kondisi oseanografi musiman perairan Selat Sunda dari analisis data multitemporal. Jakarta. Jurnal Penelitian Perikanan Indonesia. Vol.13 No.3. Desember 2007.

Anonim. 2002. Laporan akhir penelitian dinamika perairan Selat Sunda. Bidang Dinamika Laut. Proyek Penelitian IImu Teknologi Kelautan. Pusat Penelitian Oseanografi. Lembaga IImu Pengetahuan Indonesia. Jakarta.

Birowo, S. \& Uktolseja. 1981. Oceanographics feature of Sunda Strait. In Proceeding of Workshop and Coastal Resources Management of the Krakatau and Sunda Strait Report. Indonesia. Jakarta.

Hariati, T. 2005. aspek perikanan pelagis kecil dan biologi ikan layang deles (Decapterus macrosoma) di perairan Selat Sunda. Warta Penelitian Perikanan Edisi Sumber daya dan Penangkapan. Vol.11. No.5. 2005. Hal.18-22.
Hasyim, B., K. Amri, \& M. Hartuti. 1995. Pemanfaatan data penginderaan jauh NOAA-AVHRR untuk pengamatan pola arus laut dan daerah potensi penangkapan ikan. Prosiding Konvensi Nasional Pembangunan Benua Maritim Indonesia. Badan Penerapan dan Pengkajian Teknologi. Hal.149163.

Hendiarti, N., Suwarso, A. Adrian, K. Amri, R. Andiastuti, I. B. Wahyono, \& S. I. Sachoemar. 2005. Seasonal variation of pelagic fish catch arround Java. Oceanography Society Journal. Vol.18. No.4. Desember 2005. Rockvile. M. D. USA.

Laevastu, T. \& M. L. Hayes. 1980. Fisheries oceanography and ecology. Fishing News Books Ltd. London. $119 \mathrm{p}$.

Muripto, I., D. Manurung, \& Rahadian. 2000. Oceanographic features that define the Sunda Strait upwelling related to hot spot area. The Proceedings of the JSP-DGHE International Symposium on Fisheries Science in Tropical Area. Bogor. Indonesia.

Nybakken, J. W. 1992. Biologi laut: Suatu pendekatan ekologis. Alih Bahasa: E. H. E. Koesoebiono. D. G. Bengen, M. Hutomo, \& S. Sukardjo. Penerbit P. T. Gramedia. Jakarta.

Potier. M. 1988. Pecherie de layang et senneur semi industriels Javanais: Perspective Historique Approche systeme. Ph. D. Thesis. Universite de Montpellier. $280 \mathrm{p}$.

Syamsudin, F., M. Laksmini, K. Amri, \& R. Andiastuti. 2003. Hydrology of the Sunda Straits Water and its Relation with the Yield of Euthynnus Affinis Catchments in the Landing Fish Auction, Labuan, West Java. The 12 th Indonesia Scientific Meeting. Osaka University. Jepang.

Wirtky, 1962. The upwelling in the region beetwen Java and Australia during the south east monsoon. Australia. Journal Marine Freshwater Resources. 13 (3). P 217-225. 